\title{
Building a Bridge: Articulation Programs for Bibliographic Instruction
}

\section{Barbara E. Kemp, Mary M. Nofsinger, and Alice M. Spitzer}

\begin{abstract}
Recent studies have called for more integration of educational experiences and closer cooperation between high schools and colleges. Students making the transition from high school to college freguently lack library/research skills, which is a major problem for bibliographic instruction librarians. Based on models of school/college cooperation, current cooperative projects involving academic libraries are discussed. The relevance of articulation efforts between high school and university libraries is emphasized.
\end{abstract}

everal educational groups, including the American Association for Higher Education, the Carnegie Foundation for the Advancement of Teaching, and the Libraries and A Learning Society project, have called recently for closer cooperation among the nation's high schools and colleges. This desire for educational articulation, or the integration of educational experiences, takes many forms, but two common goals seem to be apparent: (1) to ease the transition of the student from one educational unit to another, and (2) to link the educational process into a lifelong learning continuum.

Unfortunately, programs and curricula often are developed or administered unilaterally. There is a "tendency of teachers and administrators to concentrate on the curriculum of their level to such an extent that they ignore the learning goals of other levels" while colleges frequently decide on admission requirements without consulting those most directly affected-the teachers and administrators of the secondary schools. ${ }^{2}$ The result is a poorly integrated, inefficient educational system, which has both gaps and unnecessary duplication in the curricula. Students and educators alike are frustrated by this discontinuity, and taxpayers are forced to bear the costs of remedial and duplicated programs.

To correct such problems, a Carnegie Foundation special report has urged that the nation's high schools and colleges "should join together to determine the content and specific skills considered essential requirements for entrance into college. ${ }^{\prime 3}$ The same report lists five principles to follow in establishing collaborative projects: (1) "educators at both levels must agree that they, indeed, have common problems"; (2) "the traditional academic 'pecking order' must be over-

Barbara E. Kemp is Head, Humanities/Social Sciences Public Services; Mary M. Nofsinger and Alice M. Spitzer are reference librarians at Washington State University Libraries, Pullman, Washington 99164-5610. This paper was presented at the ACRL Fourth National Conference in Baltimore, April 9-12, 1986. 
come"; (3) "cooperative projects must be sharply focused"; (4) "those who participate must get recognition"; and (5) "cooperation .... must focus on action-not machinery. ${ }^{\prime \prime 4}$

\section{ARTICULATION OF LIBRARY SKILLS}

As educators, it is important for academic librarians to be aware of and understand this focus on articulation and to consider bibliographic instruction efforts in relation to it. Like faculty in the subject disciplines, librarians must be prepared to establish cooperative programs with secondary schools to help students in their transition to college.

There are strong, practical arguments for collaborative efforts. Most academic libraries are requested to host classes from secondary schools or have high school students come to the reference desk for individual assistance. Since these classes and students are not always prepared with well-designed library assignments, approval for such requests is not always granted. Another drawback in this approach is that the timing often conflicts with heavy use by the academic library's primary clientele and is thus viewed as an intrusion.

By working to establish cooperative programs, the academic librarian can gain control over the situation. It can be made clear that classes are welcome when they are scheduled at times convenient to the academic calendar. Academic and school librarians need jointly to establish criteria for library assignments, define minimum library/research competencies, and establish methods of teaching them at the appropriate grade level. As a result, students are likely to be better prepared, and there would be less need for remediation. The development of mutual respect and understanding between academic librarians and secondary school teachers and librarians and a receptive attitude toward the secondary school students can also act as a strong marketing tool for the parent institution. This ultimately benefits the academic library's position within the college or university.

\section{SCHOOL/COLLEGE LIBRARY PARTNERSHIPS}

There are several models of school/college library cooperative programs. Among these are (1) high school class visits to academic libraries; (2) academic librarians working directly with high school students to provide instruction; (3) programs and privileges for special groups, such as gifted and advanced-placement students; (4) academic librarians working with school librarians at a local or state level; (5) provision of materials designed to introduce high school students to the academic library. The following programs illustrate some of these models in use.

\section{Washington State University, Pullman}

Washington State University (WSU) completed a bibliographic instruction needs assessment survey in which the data seemed to be contradictory. The vast majority of students indicated they had received instruction in library use when they were in secondary schools, yet most still had difficulty in answering basic questions about library resources and research strategies. Experience at the reference desk confirms that many students lack understanding of fundamental library concepts.

In order to determine the cause of this discrepancy, the Washington Library Media Association was contacted to initiate preliminary discussions with school librarians. When invited to speak at their 1984 annual convention, WSU librarians presented a session on "Library Research Skills for College-Bound Students. ${ }^{\prime \prime}$ Participants discussed which library skills were most needed to be an effective library user and shared ideas on how to incorporate those skills into class assignments.

The enthusiastic response to the session resulted in an invitation to repeat it at the 1985 Washington Communication Conference (which included reading specialists, high school English, journalism, and speech teachers, as well as librarians and media specialists). At the same time WSU librarians presented a preconference workshop entitled "Building the Library 
Bridge from High School to College: Strategies for Teacher-Librarian Cooperation." Here, teachers and librarians working in small teams designed class-related library projects covering skills needed for college and lifelong learning.

\section{Chickasha Cooperative Bibliographic Instruction Project, Oklahoma}

The Chickasha Cooperative Bibliographic Instruction Project was carried out by a team of librarians representing the Chickasha Public Library, the Chickasha High School Library, and the University of Sciences and Arts of Oklahoma Library. ${ }^{6}$ The goal of the project was to make library users aware of the different library resources available to them in the Chickasha area and to make participants in the program more effective library users.

Instructional programs were presented to students and community groups. Several slide tape presentations and a workbook were prepared to assist in bibliographic instruction, and individual assistance was available during the programs. Participants benefited from increased understanding of library use and resources, and the libraries benefited from increased communication among themselves and greater public visibility.

\section{University of South Carolina, Aiken}

In the fall of 1979 , librarians at the University of South Carolina, Aiken held a half-day seminar for city and county public school librarians, teachers, and language coordinators. ${ }^{7}$ Its focus was on materials related to literature in the university library and joint, cooperative services that could be offered between the schools and the university.

An outgrowth of this seminar was the establishment of a gifted child program. Each secondary school in the Aiken area can select twelve outstanding students to participate in an annual library enrichment project in which they receive a university library orientation, assistance in locating materials, and charge-out privileges. In addition, university librarians provide guided tours and instruction to secondary school students upon the request of classroom teachers.

\section{University of Massachusetts, Amherst}

Also in 1979, a study of library instruction programs in forty high schools was done by Joyce Merriam, reference librarian at the University of Massachusetts, Amherst. ${ }^{8}$ The study found that school librarians attempted to provide at least minimal amounts of library orientation and instruction to students and that the typical high school program was almost identical to that presented to freshmen at the university. Teacher apathy toward integrating library skills into classroom instruction, fragmented library instruction given on a one-to-one basis, and lack of a formal, planned bibliographic instruction program were identified as problems.

As a result of the study, Merriam recommended many changes in library instruction at both levels. Among these recommendations were (1) librarians should teach students that the same skills can be used in various types of libraries, (2) teachers should be encouraged to integrate library exercises into their curricula, (3) schools of education should prepare prospective teachers for integrating library skills into their classrooms, and (4) school and academic librarians should work together to help students make the transition from high school to academic libraries. Another result of the study was a library instruction colloquium held in Amherst in June 1979. School and academic librarians met to discuss problems, exchange ideas and samples of instructional materials, and share knowledge.

\section{The University of \\ Tennessee, Knoxville}

The University of Tennessee has initiated an active program of cooperation with fifteen high schools in Knoxville city and county. ${ }^{9}$ A videotape introduction to the library is shown by the school librarian to students prior to their visit to the university library. Students may come to the library individually, and class groups with the accompanying teacher are encouraged to take advantage of the regular bibliographic instruction program. High school teachers and advanced placement students are entitled to free library cards. The 
service is heavily used and library staff are pleased that the books in demand by high school students do not necessarily parallel those needed by university students.

In order to alleviate the problem of books not being returned promptly and to reduce library traffic, a demonstration project is being developed that will allow librarians from two high schools to dial directly into and search the university library's database. Items requested would be sent out to the library via a delivery system. Recently, a colloquium, entitled "Teachers and Librarians: Partners in Learning," was held which "brought together high school and college librarians and teachers to discuss preparing high school students to use the academic library and to be effective information consumers. ${ }^{10}$

\section{State University of New York, Albany}

In New York there is statewide interest in cooperation among high school and university libraries. At SUNY, Albany, the university library has established policies that encourage visitations from high school classes. ${ }^{11}$ Teachers must arrange in advance for the class visits, and each student must have an assignment to complete. Upon arrival, a slide tape is shown that orients the students to the library; the bibliographic instruction coordinator then explains how to access library holdings. Librarians, including those from technical services, provide small-group tours of the building before the teacher and students begin work on assignments. Because of the enthusiastic response to this program, a half-day conference was held at SUNY, Albany, in 1984. Speakers shared their knowledge gained through several years of teaching college-bound seniors. In addition, local high school librarians and teachers discussed the preparation of students for college work via assignments and field trips.

\section{THE FUTURE}

Although many library-related articulation projects currently exist, there is relatively little information about them in the library or education literature. Academic and school librarians, working together as colleagues, need to continue developing programs and to publicize them. As an investment in the future, academic librarians should also be working with students and faculty in teacher training programs to promote the importance of information-gathering skills and attitudes conducive to lifelong learning.

The future of articulation between high school and college libraries is bright. In the pursuit of educational excellence there will be an increasing demand to provide better information-gathering skills and eliminate the need for remedial instruction. Academic librarians have a responsibility to work with secondary schools to ensure that students are adequately prepared for the transition to college-level research. We should carefully consider our role in the articulation process and continue to explore the many possibilities open to us.

\section{REFERENCES}

1. Gene I. Maeroff, School and College: Partnerships in Education (Princeton, N.J.: The Carnegie Foundation for the Advancement of Teaching, 1983), p.2; American Association for Higher Education, "High School/College Partnerships," Current Issues in Higher Education Annual Series 1(1981); Alliance for Excellence: Librarians Respond to a Nation at Risk (Washington, D.C.: U.S. Dept. of Education, 1984).

2. Julius Menacker, From School to College: Articulation and Transfer (Washington, D.C.: American Council on Education, 1975), p.9.

3. Maeroff, p. viii.

4. Maeroff, p.3-5.

5. Barbara E. Kemp and Alice M. Spitzer, "Let's Connect: High School/University Cooperation in Bibliographic Instruction," Medium: Journal of the Washington Library Media Association 9:4-7 (Winter 1985). 
6. Charles R. McClure, Chickasha Cooperative Bibliographic Instruction Project: Final Evaluation (Stanford, Calif.: ERIC Document Reproduction Service, ED 203 360, 1981).

7. Telephone conversation with Susan Hollfield, Univ. of South Carolina, Aiken, Library, June 13, 1985.

8. Joyce A. Merriam, "Helping Students Make the Transition: A Study," in Carolyn A. Kirkendall, ed., Teaching Library Use Competence: Bridging the Gap from High School to College. Papers presented at the Eleventh Annual Library Instruction Conference held at Eastern Michigan University, May 7-8, 1981 (Ann Arbor, Mich.: Pierian, 1982), p.1-12.

9. Telephone conversation wih Angie LeClercq, University of Tennessee, Knoxville, Library, June 12, 1985.

10. LOEX News 13 no.1:8 (Spring 1986).

11. Telephone conversation with Jacquelyn Gavryck, bibliographic instruction coordinator at State University of New York, Albany, Library, June 12, 1985. 